\title{
HERMENÊUTICA E TEORIAS ARGUMENTATIVAS: CONTRAPOSIÇÃO OU COMPLEMENTAÇÃO
}

HERMENEUTICS AND ARGUMENTATION THEORIES: Contraposition or complementation

HERMENÉUTICA Y TEORÍAS ARGUMENTATIVAS: Contraposición o complementación

Orlando Luiz Zanon Junior ${ }^{1}$

Resumo: O objetivo do presente texto é discutir sobre a importância das perspectivas filosóficas da hermenêutica e da argumentação jurídica para construção de um novo paradigma pós-positivista da Ciência Jurídica, muito embora possam ser apresentadas como aparentemente antagônicas ou autoexcludentes. Justifica-se tal pesquisa pelo fato de que tais linhas de pensamento foram colocadas em certo grau de oposição teórica pelos seus principais expoentes, de modo a recomendar uma discussão quanto à relevância de ambas para o movimento pós-positivista. A conclusão é que, assim como não se pode negar a importância da hermenêutica para o estudo do fenômeno da compreensão (racionalidade dos indivíduos), também é inafastável a relevância

1 Juiz de Direito. Doutor em Ciência Jurídica pela UNIVALI. Dupla titulação em Doutorado pela UNIPG (Itália). Mestre em Direito Pela UNESA. Pós-graduado pela UNIVALI e pela UFSC. Professor da Escola da Magistratura de Santa Catarina (ESMESC), da Academia Judicial (AJ) e do Programa de Pós-graduação da UNIVALI. Membro da Academia Catarinense de Letra Jurídicas (ACALEJ). 
dos métodos e das regras procedimentais como instrumentos para assegurar a comunicação racional e, assim, estimular a obtenção de verdades paradigmáticas (racionalidade intersubjetiva). Quanto à metodologia empregada, destaca-se que na fase de investigação foi utilizado o método indutivo; na estimular a obtenção de verdades paradigmáticas (racionalidade intersubjetiva). Quanto à metodologia empregada, destaca-se que na fase de investigação foi utilizado o método indutivo; na fase de tratamento de dados, o cartesiano; e o texto final foi composto na base lógica dedutiva. Nas diversas fases da pesquisa, foram acionadas as técnicas do referente, da categoria, do conceito operacional e da pesquisa bibliográfica.

Palavras-chave: Hermenêutica. Teorias Argumentativas. Ciência Jurídica.

Abstract: The main objective of this paper is to discuss the importance of the philosophical perspectives of hermeneutics and legal argumentation for the construction of a new post-positivist paradigm for Legal Science, even though they may be presented as apparently antagonistic or self-excluding. This research is justified by the fact that these theories were placed with a certain degree of theoretical opposition by their main exponents. The conclusion is that just as one cannot deny the importance of hermeneutics for the study of the phenomenon of comprehension (rationality of individuals), one also cannot overlook the importance of the methods and procedural rules, as instruments for ensuring rational communication, and promoting a striving for paradigmatic truths (intersubjective rationality). In terms of methodology, the inductive method was used in the investigation stage; the Cartesian method was used in the data processing phase, and the final text was written using deductive logic. In the various stages of the research, we used the technics of category, operational concept and of bibliographic research.

Keywords: Hermeneutics. Argumentation Theories. Legal Science.

Resumen: El objetivo del presente texto es debatir sobre la importancia de las perspectivas filosóficas de la hermenéutica y de la 
argumentación jurídica para la construcción de un nuevo paradigma pospositivista de la Ciencia Jurídica, aun cuando puedan ser presentadas como aparentemente antagónicas o autoexcluyentes. Esta investigación se justifica por el hecho de que esas líneas de pensamiento fueron colocadas en cierto grado de oposición teórica por sus principales exponentes, de modo que se recomienda una discusión acerca de la relevancia de ambas para el movimiento pospositivista. La conclusión es que, así como no se puede negar la importancia de la hermenéutica para el estudio del fenómeno de la comprensión (racionalidad de los individuos), también es innegable la relevancia de los métodos y de las reglas procedimentales como instrumentos para garantizar la comunicación racional y así estimular la obtención de verdades paradigmáticas (racionalidad intersubjetiva). En cuanto a la metodología empleada, se destaca que en la fase de investigación fue utilizado el método inductivo; en la fase de tratamiento de datos, el cartesiano; y el texto final fue compuesto en la base lógica deductiva. En las diversas fases de la investigación fueron accionadas las técnicas del referente, de la categoría, del concepto operacional y de la investigación bibliográfica.

Palabras clave: Hermenéutica; Teorías Argumentativas; Ciencia Jurídica.

\section{INTRODUÇÃO}

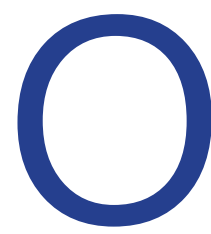

objetivo do presente texto é discutir sobre a importância das perspectivas filosóficas da hermenêutica e da argumentação jurídica para construção de um novo paradigma pós-positivista da Ciência Jurídica, muito embora possam ser apresentadas como aparentemente antagônicas ou autoexcludentes.

Notadamente, alguns autores têm defendido a substituição do modelo do Positivismo Jurídico por outro que melhor atenda às duas faces das pesquisas científicas, quais sejam, de um lado, uma descrição mais fiel da realidade e, de outro, 
a apresentação de prescrições mais avançadas para diversos problemas afetos ao sistemajurídico, inaugurando um movimento de superação paradigmática chamado de Pós-positivismo ${ }^{2}$. Cabe assinalar que esta intenção de reforma não apresenta uniformidade teórica e, aliás, os diversos autores divergem profundamente quanto aos aspectos centrais ao aperfeiçoamento da Ciência Jurídica, cabendo mencionar três vertentes principais, consistentes nos perfis substancialista (como Dworkin e Streck), procedimentalista (a exemplo de Alexy e Atienza) e pragmatista (cabendo mencionar Posner). Outros ainda, diferentemente, pretendem a manutenção do atual modelo juspositivista, mas devidamente reformulado para assimilar corretivos que o reposicionem no atual contexto constitucional, sob um viés neopositivista (cabendo citar, por todos, Ferrajoli).

Neste estudo específico, serão discutidas e comparadas especificamente a base de sustentação teórica de duas das propostas de superação pós-positivistas mais difundidas nos cenários acadêmico e forense brasileiros, consistentes na hermenêutica de cariz substancialista (proposta principalmente por Lenio Luiz Streck) e nas teorias da argumentação jurídica (com enfoque, principalmente, na proposta de Alexy). A pretensão deste artigo é destacar as contribuições de tais correntes de pensamento para o aperfeiçoamento das investigações científicas sobre o Direito (âmbito acadêmico) e, também, para o aprimoramento do sistema jurisdicional (aspecto forense ou, acaso se preferir, prático profissional). Notadamente, tais linhas de pesquisa foram colocadas em certo grau de oposição teórica pelos juristas mencionados e, assim, justifica-se uma análise para discutir a relevância de ambas para o movimento pós-positivista e, aliás, discorrer se é adequado classifica-las como excludentes ou, alternativamente, complementares.

Notadamente, o assunto tem grande relevância para o aperfeiçoamento da Ciência Jurídica, tanto que já gerou embates teóricos entre expoentes de cada uma destas linhas, cabendo mencionar, apenas para exemplificar, a recente discussão travada entre, de um lado, Atienza, defendendo a relevância das teorias procedimentalistas e, de outro, Streck e Rafael Tomaz de Oliveira, argumentando em prol da hermenêutica ${ }^{3}$.

2 KUHN, Thomas S. A estrutura das revoluções científicas. São Paulo: Perspectiva, 2009.

3 Sobre tal discussão, cabe referir os seguintes textos publicados no site Consultor Jurídico:

a) Primeiro, entrevista do Prof. Manuel Atienza, publicada sob o título "Discussão sobre ne- 
Daí que, para atingir o objetivo ora proposto, o primeiro item deste artigo científico tratará dos influxos principais da hermenêutica sobre a Teoria do Direito, de acordo com os desenvolvimentos sustentados pelo professor Streck.

A segunda parte, por outro lado, discutirá as características da argumentação jurídica, adotando como marco de investigação a construção teórica do professor Alexy.

E assim, considerando as notas apresentadas nos dois itens anteriores, será discutido sobre a prevalência de alguma das duas posturas ou, alternativamente, uma proposta de articulação entre elas, visando ao aperfeiçoamento da compreensão sobre o Direito.

Quanto à metodologia empregada, destaca-se que na fase de investigação foi utilizado o método indutivo, na fase de tratamento de dados o cartesiano e o texto final foi composto na base lógica dedutiva. Nas diversas fases da pesquisa, foram acionadas as técnicas do referente, da categoria, do conceito operacional e da pesquisa bibliográfica.

HERMENÊUTICA

Este primeiro item trata da hermenêutica, de acordo com os desenvolvimentos sustentados pelo professor Lenio Luiz Streck, em seus elementos mais basilares, em razão da sua projeção nos cenários acadêmico e forense brasileiros.

Cabe assinalar que o mencionado professor propôs a substituição do Paradigma do Positivismo Jurídico por um modelo construído mediante a

oconstitucionalismo é um acúmulo de equívocos". Disponível em: http://www.conjur.com. br/2015-set-05/entrevista-manuel-atienza-professor-universidade-alicante. Acesso em 03.05.2016; b) Segundo, comentários dos Profs. Lenio Streck e Rafael Tomaz de Oliveira, publicados sob o título "E ontologicamente impossível querer mais analítica e menos hermenêutica". Disponível em: http://www.conjur.com.br/2015-set-19/diario-classe-ontologicamente-impossivel-querer-analitica-hermeneutica. Acesso em: 03.05.2016; c) Terceiro, réplica do Prof. Manuel Atienza, publicada sob o título "Teorias da argumentação jurídica e hermenêutica não são incompatíveis". Disponível em: http://www.conjur.com.br/2015out-08/atienza-argumentacao-juridica-hermeneutica-nao-sao-incompativeis. Acesso em: 03.05.2016; e, por fim, d) Quarto, a tréplica dos Profs. Lenio Streck e Rafael Tomaz de Oliveira, publicada sob o título "Querendo ou não, para argumentar, necessito antes de hermenêutica". Disponível em: http://www.conjur.com.br/2015-out-10/diario-classe-querendo-ou-nao-argumentar-necessito-antes-hermeneutica. Acesso em: 03.05.2016. 
articulação das teorias de Martin Heidegger, Hans-Georg Gadamer e Ronald Myles Dworkin, designado de "Crítica Hermenêutica do Direito (Nova Crítica do Direito)"4. Muito embora as principais características de tal proposição teórica já tenham sido apresentadas em outro estudo mais amplo ${ }^{5}$, cabe aqui reprisar os principais influxos da hermenêutica incidentes sobre a teoria jurídica, os quais importam à discussão do referente de pesquisa (objetivo ora delimitado), para o fim de discutir quanto à possibilidade (ou não) de articulação com as teorias argumentativas.

Em uma brevíssima síntese cronológica, desenvolvida por Streck, a filosofia (conceito que engloba também as ciências até meados do século XIX ${ }^{6}$ ), no que importa especificamente à teoria do conhecimento, pode ser dividida em três fases, quais sejam: a) período da metafísica clássica, em que a relação sujeito-objeto é caracterizada pelo esforço do intérprete em compreender as características do objeto para, depois, explicitá-las utilizando a linguagem (que serviria como mero instrumento); b) etapa da metafísica moderna, na qual a relação sujeitoobjeto é dominada pelas estruturais mentais do intérprete, que descreve as coisas segundo sua percepção pessoal; e c) fase da filosofia da linguagem, em que o esquema sujeito-objeto é superado pelo sujeito-sujeito, na qual as estruturas comunicativas são condição de possibilidade de compreensão.

Explicitando tal cronologia, em uma primeira fase (letra 'a'), entendia-se que o conhecimento poderia ser adquirido pela pessoa cognoscente mediante a análise das coisas existentes na realidade fática, ou seja, que a produção do saber se estabelecia mediante uma relação entre o sujeito e o objeto. A linguagem, nesta forma de compreensão do mundo, seria apenas um meio para o sujeito expressar seu conhecimento acerca do objeto, ou seja, somente um instrumento para designação de entidades ou transmissão de ideias ${ }^{7}$.

4 STRECK, Lenio Luiz. Verdade e consenso: constituição, hermenêutica e teorias discursivas. 4. ed. São Paulo: Saraiva, 2011. p. 70.

5 ZANON JUNIOR, Orlando Luiz. Curso de filosofia jurídica. Florianópolis: Empório do Direito, 2016. p. 267-295. E também ZANON JUNIOR, Orlando Luiz. Pós-positivismo 3: a versão hermenêutica de Streck. Jus Navigandi, n. 3936, Terezina, Disponível em <www. jus.com.br>. Acesso em 01.05.2014.

6 CHAUÍ, Marilena. Introdução à História da Filosofia. V. 1. 2. ed. São Paulo: Companhia das Letras, 2002. p. 346: "Para Aristóteles e para o Ocidente, até o século XIX de nossa era, filosofia e ciência eram uma só e a mesma coisa".

7 STRECK, Lenio Luiz. Hermenêutica jurídica $\mathbf{e}(\mathbf{m})$ crise: uma exploração hermenêutica da construção do direito. 8. ed. rev. atual. Porto Alegre: Do Advogado, 2009. p. 127: "Daí 
Em uma segunda fase da teoria do conhecimento (letra 'b'), a relação entre o sujeito e o objeto foi modificada, no sentido de conferir prevalência ao primeiro (sujeito), pois sua vontade pessoal atribuiria determinadas características e contornos especiais ao entendimento do segundo (objeto). Nesta nova época, firmou-se o entendimento de que o sujeito cognoscente influenciaria determinantemente os sentidos conferidos ao objeto cognoscível, transportando, ainda que conscientemente, aspectos pessoais para sua leitura da realidade. Trata-se da fase do solipsismo (filosofia da consciência), em que as experiências individuais fixam os significados das coisas, por meio da imposição da vontade do intérprete sobre elas (as coisas são aquilo que o intérprete diz que são). Em outros termos, o sujeito solipsista (Selbstsüchtiger) é que determina o sentido do objeto conforme sua livre consciência (subjetividade assujeitadora das coisas) ${ }^{8}$.

Este segundo momento, ao que se pode perceber da narrativa de Streck, corresponderia à inovação trazida pela filosofia transcendental de Immanuel Kant quanto à teoria do conhecimento, em sua magnum opus Crítica da Razão Pura9 . O professor de Köningsberg (atualmente, Kaliningrado) mencionou ter recebido uma "grande luz", ensejadora de uma revolução copernicana na filosofia (e na ciência), pois igualmente implicava uma mudança de eixo (ou seja, ensejava uma transição paradigmática ou paradigm shift). Isto porque, consoante que, de forma resumida, sempre correndo os riscos que definições resumidas e classificações provocam na ciência, é possível afirmar que a concepção central no pensamento metafísico ocidental pressupõe um conhecimento visto como um processo de adequação do olhar ao objeto, buscando a similitude entre pensamento e coisa, desvendando as essências próprias das coisas. Em consequência, a verdade se se caracteriza exatamente pela correspondência entre o intelecto e a coisa visada, como a fórmula aristotélica e medieval. A linguagem é apenas um instrumento que comunica/transporta essências e/ou conceitos verdadeiros".

8 STRECK, Lenio Luiz. Hermenêutica jurídica $\mathbf{e}(\mathbf{m})$ crise: uma exploração hermenêutica da construção do direito. 8. ed. rev. atual. Porto Alegre: Do Advogado, 2009. p. 136: "A virada em direção à superação do essencialismo, do universalismo, embora tenha esse componente nominalista inegável (pode-se dizer, inclusive, que o positivismo jurídico inicia com o nominalismo de Ockham), passa pela ruptura com o realismo, quando o esquema sujeito objeto sofre uma transformação: surge a subjetividade assujeitadora das coisas, com o nascimento do sujeito que dominará a modernidade, atravessando o século XX e chegando no século XXI ainda fortalecido, mormente no campo do direito. Nesse novo paradigma, os sentidos não estão mais nas coisas, passando, agora, a estarem na mente (filosofia da consciência). É o princípio epocal cartesiano, denominado cogito; e, na sequência, o eu transcendental kantiano, o absoluto hegeliano e o ápice da metafísica moderna: a vontade do poder (Wille Zur Macht) de Nietzsche, onde o traço fundamental da realidade é a vontade do poder. E toda correção deve ser ajustada em relação à vontade do poder".

9 KANT, Immanuel. Crítica da razão pura. 4. ed. Petrópolis: Vozes, 2015. 
relatam os historiadores da filosofia, da mesma forma que Copérnico promoveu considerável avanço na astronomia ao desenvolver a tese de que não eram os astros que giravam em torno da terra (geocentrismo de Ptolomeu), mas sim eram os planetas que possuíam órbitas ao redor das estrelas (heliocentrismo), também Kant teria percebido, no âmbito das teorias do conhecimento, que não eram os sujeitos que eram submetidos à essência do objeto, mas sim o objeto que recebia o influxo do intelecto humano, de modo a mudar a compreensão do esquema sujeito e objeto ${ }^{10}$. Com efeito, de acordo com a proposta kantiana, a consciência humana (que ele chama de "eu penso") é o princípio último do conhecimento científico, determinante na relação entre o sujeito e o objeto, caracterizando o que se convencionou chamar de apercepção transcendental ${ }^{11}$.

Todavia, prosseguindo na síntese histórica, posteriormente, em uma terceira fase (letra ' $c$ '), Streck sustenta que teria ocorrido uma nova mudança paradigmática na teoria do conhecimento, que chamou de viragem, reviravolta ou giro linguístico (linguistic turn), segundo o qual a linguagem deixa de ser compreendida como um meio relacional entre o sujeito e o objeto, tornando-se ela a própria condição de possibilidade para a compreensão da realidade. Então, opera-se o rompimento com o modelo da filosofia da consciência de perfil kantiano, o qual é substituído pela filosofia da linguagem ${ }^{12}$.

10 REALE, Giovanni. ANTISERI, Dario. História da filosofia: de Spinoza a Kant. V. 4. São Paulo: Paulus, 2004. p. 350-351, notadamente na p. 351: "Espaço e tempo desse modo se configuram não como modos de ser das coisas [ou seja, não são realidades ontológicas], e sim como modos com os quais o sujeito capta sensivelmente as coisas. Não é o sujeito que se adequa ao objeto ao conhecê-lo, mas vice-versa, o objeto é que se adequa ao sujeito". E p. 358: "Deixando de lado a metáfora [revolução copernicana], Kant considera que não é o sujeito que, conhecendo, descobre as leis do objeto, mas sim, ao contrário, que é o objeto, quando é conhecido, que se adapta às leis do sujeito que o recebe cognoscitivamente".

11 KANT, Immanuel. Crítica da razão pura. 4. ed. Petrópolis: Vozes, 2015. p. 129-133. Ver REALE, Giovanni. ANTISERI, Dario. História da filosofia: de Spinoza a Kant. V. 4. São Paulo: Paulus, 2004. p. 364-365, cabendo extrair da p. 365: "O Eu penso, ou Apercepção transcendental, é a unidade transcendental originária e suprema da autoconsciência, que é comandada por doze categorias: ela é a autoconsciência que, enquanto produz a representação "Eu penso", constitui a possibilidade do conhecimento a priori que deriva do Eu penso: é o princípio da unidade sintética originária, a própria forma do intelecto".

12 STRECK, Lenio Luiz. Hermenêutica jurídica e(m) crise: uma exploração hermenêutica da construção do direito. 8. ed. rev. atual. Porto Alegre: Do Advogado, 2009. p. 145: "Ou seja, no paradigma da filosofia da consciência a concepção vigente é a de que a linguagem é um instrumento para designação de entidade independentes desta ou para transmissão de pensamentos pré-linguísticos, concebidos sem a intervenção da linguagem. Assim, somente depois de superar este paradigma, mediante o reconhecimento de que a linguagem tem um papel constitutivo na nossa relação com o mundo é que se pode falar em uma mudança paradigmática, representada pelo rompimento com a filosofia da consciência pela 
Nessa nova etapa, a linguagem é entendida não mais como mero instrumento que se interpõe entre a pessoa e a coisa, mas sim como o único meio de compreensão da realidade, com a função de constituição do conhecimento de forma intersubjetiva ${ }^{13}$. Assim, nesta linha de raciocínio, a relação de compreensão deixa de ocorrer entre o conhecedor e o conhecido (sujeitoobjeto), passando a consubstanciar a construção de saberes entre pessoas cognoscentes (sujeito-sujeito) ${ }^{14}$. A linguagem passa a ser a totalidade da existência, ou seja, a única forma de acesso ao mundo, haja vista que somente é possível compreender e agir por meio dela e inserido nela. O conhecimento da realidade somente ocorre onde existem signos linguísticos, de modo que apenas há coisas quando se encontram palavras para designá-las. Enquanto não se estabelecem termos ou expressões para aferição de uma determinada coisa, esta reside fora da linguagem e, consequentemente, não existe no mundo: a linguagem é a casa do $\operatorname{ser}^{15}$.

Daí que, para Streck, tal invasão da linguagem provocou uma nova revolução "copernicana" na filosofia (posterior a de Kant), com efeitos reflexos determinantes sobre a Ciência do Direito. Todavia, a sua crítica é no sentido de que a dogmática jurídica ainda não teria incorporado tais inovações, permanecendo refém da filosofia da consciência (e da relação sujeito-objeto),

filosofia da linguagem".

13 STRECK, Lenio Luiz. Hermenêutica jurídica $\mathbf{e}(\mathbf{m})$ crise: uma exploração hermenêutica da construção do direito. 8. ed. rev. atual. Porto Alegre: Do Advogado, 2009. p. 170: "A linguagem deixa de ser um instrumento de comunicação do conhecimento e passar a ser condição de possibilidade para a própria constituição do conhecimento".

14 STRECK, Lenio Luiz. Hermenêutica jurídica $\mathbf{e}(\mathbf{m})$ crise: uma exploração hermenêutica da construção do direito. 8. ed. rev. atual. Porto Alegre: Do Advogado, 2009. p. 179-180: "Conceber a linguagem como totalidade, é dizer, entender que não há mundo sem mediação do significado, significa romper com a concepção de que a um sujeito cognoscente apreendendo um objeto, mediante um instrumento chamado linguagem. Morre, assim, o cogito cartesiano e todas as formas de 'eu' puro, desindexado de cadeias significantes. Da superada (?) relação sujeito-objeto passa-se à relação sujeito-sujeito".

15 STRECK, Lenio Luiz. Hermenêutica jurídica $\mathbf{e}(\mathbf{m})$ crise: uma exploração hermenêutica da construção do direito. 8. ed. rev. atual. Porto Alegre: Do Advogado, 2009. p. 202: "A linguagem, então, é totalidade; é a abertura para o mundo; é, enfim, condição de possibilidade. Melhor dizendo, a linguagem, mais do que condição de possibilidade, é constituinte e constituidora do saber, e, portanto, do nosso modo-de-ser-no-mundo, que implica as condições de possibilidade que temos para compreender e agir. Isto porque é pela linguagem e somente por ela que podemos ter o mundo e chegar a esse mundo. Sem linguagem não há mundo, enquanto mundo. Não há coisa alguma onde falta a palavra. Somente quando se encontra a palavra para a coisa é que a coisa é uma coisa". 
de modo a inviabilizar o seu aprimoramento segundo o novo Paradigma da filosofia da linguagem, conforme assinalado pela Crítica Hermenêutica do Direito (Nova Crítica do Direito) ${ }^{16}$.

Outrossim, o professor rio grandense propõe uma modificação no paradigma de sustentação da Teoria do Direito, construída mediante uma simbiose entre os legados teóricos de Heidegger, Gadamer e Dworkin, com a finalidade de superar os defeitos do modelo ainda prevalecente do Positivismo Jurídico, observada a já sintetizada revolução científica proporcionada pela filosofia da linguagem ${ }^{17}$. $\mathrm{E}$, dentre os principais influxos desta reviravolta linguística na Ciência Jurídica, cabe destacar quatro aspectos em particular, quais sejam, primeiro: a) superação do esquema sujeito-objeto pelo sujeito-sujeito; b) negação de um método para interpretação jurídica; c) a inviabilidade da divisão da atividade interpretativa em fases; e d) a importância do círculo hermenêutico e da diferença ontológica, mormente como escudos instrumentais contra decisionismos e arbitrariedades judiciais.

No tocante ao primeiro aspecto (letra 'a'), o pensador em tela destaca ser crucial que o intérprete e aplicador (representando precipuamente na figura do juiz) deve compreender a evolução ocorrida na teoria do conhecimento, antes exposta, para o fim de superar o esquema sujeito-objeto inerente à metafísica moderna, passando da subjetividade assujeitadora das coisas (filosofia da consciência) para relação de intersubjetividade, mediante a compreensão da linguagem como condição de possibilidade para construção

16 STRECK, Lenio Luiz. Hermenêutica jurídica $\mathbf{e}(\mathbf{m})$ crise: uma exploração hermenêutica da construção do direito. 8. ed. rev. atual. Porto Alegre: Do Advogado, 2009. p. 224: "Importa referir que uma hermenêutica jurídica trabalhada desde a matriz gadameriana e da ontologia fundamental heideggeriana implica um novo olhar sobre o Direito. Não tenho receio em afirmar que esse (novo) paradigma implica uma ruptura com toda uma tradição no campo jurídico, problemática que procuro enfrentar a partir do que venho denominando de Nova Crítica do Direito".

17 STRECK, Lenio Luiz. Hermenêutica jurídica $\mathbf{e}(\mathbf{m})$ crise: uma exploração hermenêutica da construção do direito. 8. ed. rev. atual. Porto Alegre: Do Advogado, 2009. p. 334: "Portanto, o que venho procurando sustentar e demonstrar é que a assim denominada 'viragem hermenêutico-ontológica', provocada por Sein und Zeit (1927) de Martin Heidegger, e a publicação, anos depois, de Warheit und Methode (1960), por Hans-Georg Gadamer, foram fundamentais para um novo olhar sobre a hermenêutica jurídica. [...] $E$, para além dos objetivismos e subjetivismos, a hermenêutica filosófica abre um novo espaço para a compreensão do direito e tudo o que representa a revolução copernicana proporcionada pelo novo constitucionalismo. [..] É exatamente neste contexto que exsurgem as possibilidades da superação do positivismo pelo (neo)constitucionalismo". 
do conhecimento, não mero instrumento que se interpõe entre a pessoa cognoscente e o objeto cognoscível ${ }^{18}$.

Concernente ao segundo ponto (letra 'b'), Streck ressalta a importância de o hermeneuta (reitera-se que visualizado como o juiz) negar a existência de um método explicativo do fenômeno de compreensão, justamente porque este chegaria tarde, quando já inaugurado o processo de conhecimento ${ }^{19}$. Ou seja, o sujeito não escolhe um método (ou vários) para interpretar, haja vista que a exposição ao mundo já lhe confere sentidos de forma imediata, de acordo com sua compreensão prévia acumulada (pré-compreensão) ${ }^{20}$. Ora, o juiz, ao tomar contato com um caso concreto específico, automaticamente forma sua compreensão de acordo com sua carga de preconceitos e, portanto, seria supérfluo um posterior método de interpretação.

Sobre o terceiro item (letra ' $c$ '), o jurista em questão explica que a negação de um método, nos termos antes expostos, implica a impossibilidade de divisão do processo interpretativo em fases, sob o argumento de que a compreensão ocorre mediante uma fusão entre os horizontes (ou pontos de vista históricos) do intérprete e da mensagem escrita ou verbal ${ }^{21}$. Notadamente, o intérprete está inserido no mundo por meio da linguagem e, nesta condição, possui uma carga de conhecimentos previamente adquiridos (prejuízos ${ }^{22}$ ), ou seja, um horizonte de 18 STRECK, Lenio Luiz. Hermenêutica jurídica $\mathbf{e}(\mathbf{m})$ crise: uma exploração hermenêutica da construção do direito. 8. ed. rev. atual. Porto Alegre: Do Advogado, 2009. p. 176-178 e 182-183.

19 STRECK, Lenio Luiz. Verdade e consenso: constituição, hermenêutica e teorias discursivas. 4. ed. São Paulo: Saraiva, 2011. p. 135: "O procedimento implica um puro espaço lógico, uma troca de argumentos. Só que cada um já vem de um lugar de compreensão, que é a pré-compreensão".

20 STRECK, Lenio Luiz. Verdade e consenso: constituição, hermenêutica e teorias discursivas. 4. ed. São Paulo: Saraiva, 2011. p. 494: "Insisto: a pré-compreensão é uma espécie de todo que sempre nos antecipa quando nos relacionamos com os entes do mundo. Em hipótese alguma isso representa uma ideia, mas, pelo contrário, isso é possibilitado por um ver fenomenológico que acessou o mundo prático em suas estruturas mais originárias".

21 STRECK, Lenio Luiz. Hermenêutica jurídica $\mathbf{e}(\mathbf{m})$ crise: uma exploração hermenêutica da construção do direito. 8. ed. rev. atual. Porto Alegre: Do Advogado, 2009. p. 213: "O caráter de interpretação em Gadamer é sempre produtivo. É impossível reproduzir um sentido. O aporte produtivo do intérprete forma inexoravelmente parte do sentido da compreensão. Como já se viu, é impossível o intérprete se colocar em lugar do outro. O acontecer da interpretação ocorre a partir de uma fusão de horizontes (Horizontverschmelzung), porque compreender é sempre o processo de fusão dos supostos horizontes para si mesmo, acentua. Compreender uma tradição requer um horizonte histórico. Um texto histórico somente é interpretável desde a historicidade (consciência histórico-efetual) do intérprete".

22 STRECK, Lenio Luiz. Hermenêutica jurídica $\mathbf{e}(\mathbf{m})$ crise: uma exploração hermenêutica da construção do direito. 8. ed. rev. atual. Porto Alegre: Do Advogado, 2009. p. 122: "Op- 
compreensão já estabelecido. Igualmente, um texto (a exemplo dos enunciados legais) foi constituído em determinado momento histórico com determinados signos linguísticos e, assim, também ostenta um horizonte de significados, que dizem algo ao leitor ${ }^{23}$. Outrossim, tanto o intérprete como o texto já carregam uma carga linguística prévia, porquanto não existe o "grau zero" de significados, ou seja, não há uma tábula rasa ou um quadro em branco isentos de qualquer interferência anterior ${ }^{24}$. Então, através da leitura do texto ou da oitiva do outro, firma-se uma fricção entre os espectros de compreensão do intérprete e do texto (ou do interlocutor), na medida em que ambos se condicionam mutuamente, de modo que o resultado da interpretação não é a reprodução de um sentido já existente (Auslegung), mas sim a atribuição de um novo significado (Sinngebung), caracterizado justamente pela fusão de horizontes (Horizontverschmelzung) ${ }^{25}$.

E, por fim, quanto ao quarto ponto (letra 'd'), Streck acentua a importância do círculo hermenêutico (hermeneutische Zirkel) e da diferença ontológica (ontologische Differenz) como elementos para blindagem contra decisionismos e arbitrariedades judiciais.

O círculo hermenêutico é uma metáfora que demonstra o movimento de compreensão firmado entre o intérprete e o texto (ou a comunicação verbalizada). A dinâmica circular se estabelece entre os prejuízos trazidos pelo intérprete e o conteúdo da mensagem a ser conhecida, de modo que a atribuição de sentido

tou-se, ainda, por traduzir as expressões 'preconceitos' ou 'prejuízos' por pré-juízos, em face do preconceito que existe em torno desses termos em nossa linguagem cotidiana".

23 STRECK, Lenio Luiz. Hermenêutica jurídica $\mathbf{e}(\mathbf{m})$ crise: uma exploração hermenêutica da construção do direito. 8. ed. rev. atual. Porto Alegre: Do Advogado, 2009. p. 211: "Para Gadamer, aquele que pretende compreender não pode entregar-se desde o princípio à sorte de suas próprias opiniões prévias e ignorar a mais obstinada e consequentemente opinião do texto. Aquele que pretende compreender um texto tem que estar em princípio disposto a que o texto Ihe diga algo. Uma consciência formada hermeneuticamente tem que se mostrar receptiva desde o início para a condição do texto".

24 STRECK, Lenio Luiz. Hermenêutica jurídica $\mathbf{e}(\mathbf{m})$ crise: uma exploração hermenêutica da construção do direito. 8. ed. rev. atual. Porto Alegre: Do Advogado, 2009. p. 212: "Quem compreende não tem uma mente em branco, como uma tábula rasa, e sim já tem, desde sempre, uma prévia compreensão das coisas e do mundo; já tem (sempre) uma précompreensão, algo prévio que vem com o ente, como curador/vigilante do ser".

25 STRECK, Lenio Luiz. Hermenêutica jurídica $\mathbf{e}(\mathbf{m})$ crise: uma exploração hermenêutica da construção do direito. 8. ed. rev. atual. Porto Alegre: Do Advogado, 2009. p. 215: "A fusão de horizontes se dá pela aplicação. O ato de interpretar implica uma produção de um novo texto, mediante a adição do sentido que o intérprete Ihe dá. Essa adição de sentido decorre da consciência histórico-efetual na qual o intérprete está possuído. Isto porque há caráter construtivista na história". 
ocorre mediante o influxo alternado e interdependente das partes (palavras, orações e frases) e do todo (conjunto do texto). Ou seja, segundo a lógica interna do círculo hermenêutico, somente é possível compreender as partes através do todo, bem como a totalidade apenas pode ser interpretada pela significação das respectivas parcelas, mediante o fluxo circular balizado pelos prejuízos portados pelo intérprete ${ }^{26}$. Daí que, segundo o autor em tela, esta explicação, que não consubstancia um método, é crucial para o mais amplo entendimento da interpretação jurídica.

De outro lado, a diferença ontológica, ou seja, a discrepância entre ser (Sein) e ente (Seiende), é considerada por ele como essencial para preservar a ciência da objetivação (entificação) pretendida pela metafísica ${ }^{27}$. Segundo o autor, o ser é a revelação ou a apresentação da coisa. Para que o ser se manifeste, contudo, é necessário um espaço vazio, ou seja, uma clareira. O ser humano consubstancia tal clareira ou abertura onde ocorre o desvelamento do ser (Unverborgenheit) e, assim, ostenta a condição de compreender os entes. O ente por si só é inacessível, somente se manifestando no seu ser, de modo que ambos estão interligados, na medida que o ente somente se faz presente no seu ser e vice-versa ${ }^{28}$. Streck transporta tal entendimento para Ciência Jurídica, argumentando que existe a diferença ontológica entre textos e Normas, precisamente porque a Norma "é o 26 STRECK, Lenio Luiz. Hermenêutica jurídica $\mathbf{e}(\mathbf{m})$ crise: uma exploração hermenêutica da construção do direito. 8. ed. rev. atual. Porto Alegre: Do Advogado, 2009. p. 275: "Jamais haverá, pois, uma leitura ingênua, porque o intérprete leva consigo uma compreensão prévia daquilo que quer compreender. Entre essa compreensão prévio e o texto (fato, norma, etc.) se dá, pois, uma relação de circularidade típica, um círculo que pode frustrar a compreensão definitiva, porém que é certamente algo positivo, porque não há forma de entender uma coisa que não seja inserindo-a em uma bagagem de conhecimentos prévios que permitem que essa coisa desdobre todo sentido que encerra. O círculo hermenêutico que se produz entre o texto e o leitor não é senão uma nova versão, uma versão extremada do círculo intelectivo que a hermenêutica clássica havia observado que se dá entre a totalidade de uma obra literária e as partes que a compõem. Não se pode entender o sentido de um texto se não houver entendido o sentido de cada uma de suas partes, porém tampouco se entende plenamente o sentido de cada uma das partes até conseguir a compreensão da obra".

27 STRECK, Lenio Luiz. Hermenêutica jurídica $\mathbf{e}(\mathbf{m})$ crise: uma exploração hermenêutica da construção do direito. 8. ed. rev. atual. Porto Alegre: Do Advogado, 2009. p. 208: "Assim, aprender e guardar (proteger) a diferença ontológica é o que preserva a ciência da total objetivação, o que somente resulta da destruição, desconstrução e superação da metafísica, que entificou o ser e assim encobriu a diferença, sobretudo na modernidade".

28 STRECK, Lenio Luiz. Hermenêutica jurídica $\mathbf{e}(\mathbf{m})$ crise: uma exploração hermenêutica da construção do direito. 8. ed. rev. atual. Porto Alegre: Do Advogado, 2009. p. 197-207. 
sentido do ser do ente (texto)"29. Sob esta ótica, a Norma Jurídica não é uma "capa de sentido" a ser acoplada a um texto, mas sim uma faceta inseparável dele, de modo que um não pode existir no mundo isoladamente do outro ${ }^{30}$. Outrossim, "não se interpreta o texto [isoladamente], mas o texto em sua historicidade e faticidade, que vai constituir a 'norma'. Norma é, assim, o texto aplicado/concretizado"31.

Para encerrar este primeiro subitem do texto, cabe anotar que as quatro referidas considerações acerca da hermenêutica, antes delineadas, norteiam a proposta pós-positivista de Streck, que as aponta como cruciais para o aperfeiçoamento do sistema jurídico.

\section{TEORIAS ARGUMENTATIVAS}

Este segundo item discute as características da argumentação jurídica, adotando como marco de investigação a construção teórica do professor Alexy.

Iniciando sobre este ponto, cabe assinalar que, enquanto a hermenêutica enfoca a compreensão de um intérprete individualizado, inserido num cenário de linguagem compartilhada, de outro lado, as teorias argumentativas (discursivas ou procedimentais) dedicam-se principalmente à análise da tomada de decisões mediante um discurso intersubjetivo, que deve obedecer a regras procedimentais específicas, tendentes à formação de um consenso entre pessoas em igualdade de condições (paridade de armas), as quais visam conferir maior qualidade e legitimidade à construção do resultado, embora não possam assegurar a obtenção de correção absoluta32. Daí que autores como Jürgen Habermas, Chaïm Perelman, 29 STRECK, Lenio Luiz. Hermenêutica jurídica $\mathbf{e}(\mathbf{m})$ crise: uma exploração hermenêutica da construção do direito. 8. ed. rev. atual. Porto Alegre: Do Advogado, 2009. p. 226.

30 STRECK, Lenio Luiz. Hermenêutica jurídica $\mathbf{e}(\mathbf{m})$ crise: uma exploração hermenêutica da construção do direito. 8. ed. rev. atual. Porto Alegre: Do Advogado, 2009. p. 226: "Eu não vislumbro primeiramente o texto para depois 'acoplar' a respectiva norma. A 'norma' não é uma 'capa de sentido', que existiria apartada do texto. Ao contrário disto, quando me deparo com o texto, ele já ex-surge normado, a partir de minha condição de ser-no-mundo".

31 STRECK, Lenio Luiz. Hermenêutica jurídica $\mathbf{e}(\mathbf{m})$ crise: uma exploração hermenêutica da construção do direito. 8. ed. rev. atual. Porto Alegre: Do Advogado, 2009. p. 323.

32 ALEXY, Robert. Direito, razão, discurso: estudos para a filosofia do direito. Porto Alegre: Do Advogado, 2010. p. 103: "A teoria do discurso é uma teoria procedimental da correção prática. Segundo ela, uma norma é, então, correta e, por conseguinte, válida, quando ela pode ser o 
Neil MacCormick, Robert Alexy e Manuel Atienza, dentre muitos outros, conferem maior atenção aos procedimentos de tomada de decisões, considerando que as pessoas envolvidas em atividades deliberativas sustentam argumentos baseados em pontos de vista diferentes, de modo a existir dificuldade para o estabelecimento de consensos.

O fundamento de base destas teorias é no sentido de que, em um cenário democrático e heterogêneo, as pessoas precisam respeitar e considerar as opções e as sugestões dos outros para, por meio de um procedimento que permita igualdade de participação, chegar a um consenso sobre qual a deliberação mais adequada. Isto porque, na ausência de um critério definitivo para garantir a verdade e a correção absoluta da solução proposta por cada integrante da Sociedade, é preciso permitir a participação de todos, com isonomia, para fins de busca de um consenso quanto à decisão a ser tomada.

Daí que, de acordo com os adeptos das teorias argumentativas, a elaboração de processos para otimizar a comunicação se mostra importante como parâmetro para delimitar as estratégias de diálogo e, assim, racionalizar a obtenção de consensos, de modo a promover um resultado livre de arbítrio e coação. A importância das teorias discursivas e argumentativas é justamente a de que, por meios formais, esforça-se em desenvolver procedimentos que visam otimizar a obtenção de resultados e, assim, auxiliar na formação de verdades transitórias. Sob este prisma de análise, a procedimentalização dos discursos, no nível intersubjetivo, amplifica a igualdade e a segurança na obtenção de consensos, de modo a atestar que, apesar de sua estrutura formal, promove valores substanciais.

Adicionalmente, cabe assinalar que, no plano teórico, os procedimentalistas, em geral, renegam a possibilidade da aplicação de Normas Jurídicas somente segundo um modelo de perfil lógico dedutivo, a exemplo da subsunção, de modo a contrariar o padrão científico do Positivismo Jurídico precisamente neste ponto (sem olvidar de discrepâncias adicionais). Neste particular, Atienza esclarece que "justificar uma decisão, num caso difícil, significa algo mais do que efetuar teoria da fundamentação jurídica. 3. ed. Rio de Janeiro: Forense, 2011. p. 179. 
uma operação dedutiva que consiste em extrair uma conclusão de premissas normativas e fáticas" ${ }^{\prime 3}$. Daí exsurge a necessidade de construir um novo modelo ou método de construção e justificação das conclusões, de perfil argumentativo, para complementar ou substituir a lógica subsuntiva de aplicação normativa. E, nesta ótica, resta possível afirmar que, "de certo modo, a teoria da argumentação jurídica é a versão contemporânea da velha questão do método jurídico" ${ }^{34}$, ou seja, trata de como proceder para fundamentar uma decisão jurídica de forma legítima, ultrapassando a univocidade do silogismo lógico dedutivo (subsunção).

Para exemplificar tal assunto, aqui cabe adotar a proposta teórica de Robert Alexy como modelo discursivo para a Ciência Jurídica, considerando sua ampla projeção nos cenários acadêmicos brasileiro e europeu, ao ponto de Atienza considerar que tal teoria, ao lado também da proposta de Neil MacCormick, corresponde à "teoria padrão da argumentação" para o cenário do civil law (ou code based legal system) ${ }^{35}$.

Com tal propósito em tela, cabe acentuar que o professor da Christian-AlbrechtsUniversität desenvolveu uma teoria do Direito de caráter "não positivista" (ou seja, de corte pós-positivista) ${ }^{36}$ com o escopo de responder indagações sobre direitos fundamentais ${ }^{37}$. Sua proposta pode ser caracterizada como uma "sistematização e reinterpretação da teoria do discurso prático habermasiana" transportada para "o campo específico do Direito"38. Dito isto, para atender o referente de pesquisa proposto, cabe reprisar brevemente a descrição dos aspectos de tal proposição teórica mais afinados com a base argumentativa, com fulcro em estudos já efetuados anteriormente ${ }^{39}$.

33 ATIENZA, Manuel. As razões do direito: teoria da argumentação jurídica. 2. ed. Rio de Janeiro: Forense, 2014. p. 8-9.

34 ATIENZA, Manuel. As razões do direito: teoria da argumentação jurídica. 2. ed. Rio de Janeiro: Forense, 2014. p. 132.

35 ATIENZA, Manuel. As razões do direito: teoria da argumentação jurídica. 2. ed. Rio de Janeiro: Forense, 2014. p. 259.

36 ALEXY, Robert. Conceito e validade do direito. São Paulo: Martins Fontes, 2009. p. 3.

37 ALEXY, Robert. Teoria dos direitos fundamentais. São Paulo: Malheiros, 2008. p. 25.

38 ATIENZA, Manuel. As razões do direito: teoria da argumentação jurídica. 2. ed. Rio de Janeiro: Forense, 2014. p. 187.

39 PASOLD, Cesar Luiz. ZANON JUNIOR, Orlando Luiz. Pós-positivismo 1: A versão procedimentalista de Alexy. Revista Jurídica Cesumar - Mestrado, v. 13, n. 1, p. 131-159, 2013. Também ZANON JUNIOR, Orlando Luiz. Curso de filosofia jurídica. Florianópolis: Empório do Direito, 2016. p. 192-223. 
Para atingir tal desiderato, importa ressaltar que sua proposição é no sentido de que a racionalidade na construção de Normas Jurídicas depende da sua formação por meio de um discurso conduzido segundo Regras estabelecidas, que visam promover a correção do resultado ${ }^{40}$. De acordo com Alexy, "da possibilidade de uma argumentação jurídica racional dependem não só o caráter científico da Ciência do Direito, mas também a legitimidade das decisões judiciais"41. Mais do que isto, a própria justiça da Decisão está condicionada ao cumprimento dos estritos critérios argumentativos pelos participantes do discurso jurídico ${ }^{42}$.

Conforme Alexy, "os discursos são um conjunto de ações interconectadas nos quais se comprova a verdade ou correção das proposições"43. Muito embora tal comprovação discursiva certamente não tenha condições de atingir uma certeza definitiva, a condução da argumentação segundo Regras prefixadas garante a racionalidade do resultado, expõe explicitamente os fundamentos decisórios e, consequentemente, viabiliza um controle mais amplo da produção normativa ${ }^{44}$.

Fixada esta ideia, cabe apresentar quatro fundamentos procedimentalistas que são cruciais para a proposição paradigmática em tela, quais sejam: a) a tese de que o discurso jurídico (leia-se o processo judicial) é um caso especial do discurso prático geral (ou seja, da discussão moral); b) a possibilidade de atingimento de um resultado apenas formalmente correto, ou seja, a inviabilidade de se atingir (ou, ao menos, de comprovar o atingimento de) uma única resposta correta em cada caso controvertido (ou seja, a negação da one right answer thesis de Dworkin); c) o enfoque da racionalidade discursiva na coerência decisória; e d) o conceito

40 ALEXY, Robert. Direito, razão, discurso: estudos para a filosofia do direito. Porto Alegre: Do Advogado, 2010. p. 103: "A teoria do discurso é uma teoria procedimental da correção prática. Segundo ela, uma norma é, então, correta e, por conseguinte, válida, quando ela pode ser o resultado de um determinado procedimento, ou seja, de um discurso prático racional".

41 ALEXY, Robert. Teoria da argumentação jurídica: a teoria do discurso racional como teoria da fundamentação jurídica. 3. ed. Rio de Janeiro: Forense, 2011. p. XI.

42 ALEXY, Robert. Teoria da argumentação jurídica: a teoria do discurso racional como teoria da fundamentação jurídica. 3. ed. Rio de Janeiro: Forense, 2011. p. 33-34: "Uma norma ou um mandamento singular que satisfaçam os critérios determinados pelas regras dos discursos podem ser qualificados de justos".

43 ALEXY, Robert. Teoria da argumentação jurídica: a teoria do discurso racional como teoria da fundamentação jurídica. 3. ed. Rio de Janeiro: Forense, 2011. p. 179.

44 ALEXY, Robert. Teoria da argumentação jurídica: a teoria do discurso racional como teoria da fundamentação jurídica. 3. ed. Rio de Janeiro: Forense, 2011. p. 179: "O cumprimento destas regras certamente não garante a certeza definitiva de todo o resultado, mas caracteriza o resultado como racional". 
operacional de "pretensão de correção" como elementar para a racionalidade do discurso e, também, como ponto de ligação entre moralidade e juridicidade.

No tocante ao primeiro aspecto (letra 'a), Alexy defende que o "discurso jurídico", de cunho acadêmico ou forense, é uma modalidade específica do gênero "discurso prático geral" 45 . Para ele, "nos discursos jurídicos trata-se da justificação de um caso especial de proposições normativas, as decisões jurídicas"46. Outrossim, no processo judicial, devem ser respeitadas regras específicas, além daquelas comuns ao discurso geral, de modo a viabilizar a construção de Normas Jurídicas de modo racional e científico, consoante a Tabela de Regras constante do apêndice do seu livro Teoria da Argumentação Jurídica ${ }^{47}$. Entre tais regramentos específicos, estão "a liberdade de contradição, a universalidade no sentido de um uso consistente dos predicados empregados, a clareza conceitual-idiomática, a verdade empírica, a consideração das consequências, o ponderar, a troca de papéis e a análise do nascimento de convicções morais"48.

No concernente ao segundo ponto (letra 'b'), cabe assinalar que as teorias discursivas, embora visem assegurar a racionalidade da construção normativa e viabilizar o controle das decisões, promovem apenas um resultado formalmente correto ${ }^{49}$. Sem embargo, os procedimentalistas ainda não alcançaram a elaboração de critérios que assegurem a obtenção de um resultado substancialmente correto, a exemplo do que supostamente ocorre com as demais áreas do conhecimento ${ }^{50}$.

45 ALEXY, Robert. Teoria da argumentação jurídica: a teoria do discurso racional como teoria da fundamentação jurídica. 3. ed. Rio de Janeiro: Forense, 2011. p. 31: "O que se pretende desenvolver é uma teoria analítico-normativa do discurso jurídico. De importância central para isso é a ideia de que o discurso jurídico é um caso especial do discurso prático geral. [...] No discurso jurídico, trata-se de um caso especial, porque a argumentação jurídica ocorre sob uma série de condições limitadoras".

46 ALEXY, Robert. Teoria da argumentação jurídica: a teoria do discurso racional como teoria da fundamentação jurídica. 3. ed. Rio de Janeiro: Forense, 2011. p. 219.

47 ALEXY, Robert. Teoria da argumentação jurídica: a teoria do discurso racional como teoria da fundamentação jurídica. 3. ed. Rio de Janeiro: Forense, 2011. p. 287-293.

48 ALEXY, Robert. Constitucionalismo discursivo. 2. ed. Porto Alegre: Do Advogado, 2008. p. 26.

49 ALEXY, Robert. Teoria da argumentação jurídica: a teoria do discurso racional como teoria da fundamentação jurídica. 3. ed. Rio de Janeiro: Forense, 2011. p. 295: "A teoria do discurso é uma teoria procedimental. Segundo ela, uma norma só é correta se pode ser resultado de um procedimento definido por meio das regras do discurso".

50 ALEXY, Robert. Teoria da argumentação jurídica: a teoria do discurso racional como teoria da fundamentação jurídica. 3. ed. Rio de Janeiro: Forense, 2011. p. 284: "Tampouco nas ciências naturais, que foram com frequência contrapostas à Ciência do Direito como paradigma de verdadeiras ciências, pode-se falar da formação de uma segurança definitiva. [...]. Não é a produção de segurança que constitui o caráter racional da Ciência do Direito, 
Daí que, para teoria em tela, a análise da correção do resultado está relacionada com a observância aproximada das Regras do discurso, independentemente da obtenção de um consenso ${ }^{51}$.

Com efeito, as teorias procedimentalistas admitem a relatividade das soluções produzidas por meio do discurso, pois a argumentação jurídica pode resultar em decisões diversas para um mesmo caso, ainda que observadas integralmente as Regras do diálogo. Daí resulta a rejeição de Alexy quanto à tese de que para toda hipótese existe uma única resposta correta (the one right answer thesis), desenvolvida por Dworkin. Tal negativa está calcada no fato de que não existem critérios que permitam confirmar se uma determinada solução é a única certa para um caso específico, razão pela qual tal tese possui um caráter absoluto impossível de ser comprovado ${ }^{52}$. Por isto, o autor em exame prefere estabelecer que "uma única resposta correta é a finalidade a que se deve aspirar", ou seja, uma pretensão meramente ideal do discurso jurídico (daí exsurge o conceito operacional de "pretensão de correção") ${ }^{53}$.

Quanto ao terceiro item (letra 'c), cabe anotar que o jurista em questão defende que a coerência amplia a racionalidade da argumentação dentro de um sistema jurídico e, assim, merece ser promovida. Tal manifestação favorável à coerência, como fator de aprimoramento do discurso, reflete um certo grau de aderência à tese da necessidade de preservação da integridade do Direito

mas o cumprimento de uma série de condições, critérios ou regras, os quais este trabalho tenta evidenciar. Sua apresentação sistemática pode ser vista como uma explicação do conceito de argumentação jurídica racional".

51 ALEXY, Robert. Direito, razão, discurso: estudos para a filosofia do direito. Porto Alegre: Do Advogado, 2010. p. 95: "É, por conseguinte, não acertado imputar à teoria do discurso que ela considera o consenso como fundamento para a correção ou a verdade. Não o consenso, mas a realização do procedimento segundo as regras do discurso é o critério de correção verdadeiro da teoria do discurso".

52 ALEXY, Robert. Direito, razão, discurso: estudos para a filosofia do direito. Porto Alegre: Do Advogado, 2010. p. 95: "Seu defeito é que a suposição, que está na sua base, da existência, independente de um procedimento, de uma resposta unicamente correta para cada questão prática apresenta uma tese ontológica, que não só é difícil de fundamentar, mas também não é muito plausível. Respostas para questões práticas baseiam-se, sem dúvida, não só, mas essencialmente, também em interpretações de interesses e ponderações de interesses. Não pode ser aceito que, sobre essa base, para cada questão prática sempre somente é possível, rigorosamente, uma resposta. A tese da existência de uma resposta unicamente correta para cada questão apresenta, com isso, pelo menos, no âmbito do prático, uma ficção ontológica que não pode ser justificada".

53 LEXY, Robert. Teoria da argumentação jurídica: a teoria do discurso racional como teoria da fundamentação jurídica. 3. ed. Rio de Janeiro: Forense, 2011. p. 306-307. 
(law as integrity), proposta por Dworkin ${ }^{54}$. Contudo, para Alexy, o conceito de coerência está mais diretamente relacionado com a fundamentação jurídica, no sentido de que se trata da escorreita articulação das diversas proposições normativas integrantes de um mesmo sistema ${ }^{55}$. No seu entender, a importância da coerência reside em aperfeiçoar a racionalidade discursiva, porque uma construção articulada de normas, explorada institucionalmente, permite reunir, examinar, estabilizar, controlar e evoluir a produção jurídica ao longo do tempo. Ademais, facilita a tarefa do intérprete, haja vista que ele pode se apoiar em proposições já revisadas múltiplas vezes, de modo a facilitar a fundamentação das Decisões ${ }^{56}$.

$E$, no atinente ao quarto ponto (letra 'd'), consigna-se o posicionamento do autor quanto à preponderância das teorias argumentativas perante as de cunho hermenêutico, sob a justificativa de que a atribuição de sentidos deve objetivar a "pretensão de correção" e ser revisável publicamente. Por uma pretensão de correção (einen Auspruch auf Richtigkeit), designa-se a atitude do intérprete, participante do discurso racional, em sinceramente considerar que os argumentos invocados são válidos e, portanto, aplicáveis à espécie, sob pena de incorrer em falha performática e contaminar o processo ${ }^{57}$. Aqui cabe anotar que o requisito de possibilidade de revisão pública da justificação (acountability) evidencia o caráter procedimentalista da teoria de Alexy, precisamente por submeter a hermenêutica à teoria do discurso.

Encerrando o segundo subitem do texto, ressalta-se que as quatro referidas considerações acerca da racionalidade discursiva balizam a proposição pós-positivista de Alexy, para quem são cruciais ao desenvolvimento da Ciência Jurídica.

54 ALEXY, Robert. Constitucionalismo discursivo. 2. ed. Porto Alegre: Do Advogado, 2008. p. 117-118.

55 ALEXY, Robert. Constitucionalismo discursivo. 2. ed. Porto Alegre: Do Advogado, 2008. p. 119: "Sobre essa base deve ser dada a determinação geral subsequente do conceito de coerência: Quanto melhor é a estrutura da fundamentação de uma classe de declarações, tanto mais coerente é essa classe de declarações".

56 ALEXY, Robert. Constitucionalismo discursivo. 2. ed. Porto Alegre: Do Advogado, 2008. p. 129.

57 ALEXY, Robert. Conceito e validade do direito. São Paulo: Martins Fontes, 2009. p. 4951. E, ainda, ATIENZA, Manuel. As razões do direito: teoria da argumentação jurídica. 2. ed. Rio de Janeiro: Forense, 2014. p. 188. 


\section{EMBATE TEÓRICO ENTRE HERMENÊUTICA E PROCEDIMENTALISMO}

Neste terceiro e último subitem do presente artigo científico, serão consideradas as notas apresentadas nas duas seções anteriores para o fim de discutir se o aperfeiçoamento da Teoria Jurídica reside na adoção de uma das duas linhas filosóficas antes expostas ou, alternativamente, enseja a construção de uma proposição paradigmática que consiga promover a articulação coerente de ambas.

No atual estágio da discussão, ao menos considerando os autores de maior projeção no cenário brasileiro quanto às duas correntes em tela, verifica-se um considerável grau de antagonismo teórico entre, de um lado, os adeptos da filosofia hermenêutica e, de outro, os defensores das teorias procedimentais, argumentativas ou discursivas. Porém, o núcleo de tal contraposição não reside, necessariamente, em negar validade descritiva ou utilidade prescritiva para a outra corrente, ao menos não em todos os seus aspectos, mas sim em optar por uma postura de conferir maior importância para um campo de estudo em detrimento do outro.

De um dos polos deste debate teórico, Streck defende que a hermenêutica é mais relevante que as teorias argumentativas, porquanto configura uma etapa inicial do fenômeno da interpretação e, precisamente por isto, adquire importância prioritária para a descrição e a normatização da atividade decisória.

Notadamente, segundo o jusfilósofo em questão, uma característica marcante da hermenêutica jurídica é o enfoque no controle da correção material da aplicação jurídica já no primeiro contato linguístico do intérprete e aplicador com o caso concreto, ou seja, na profundidade gnosiológica referente à compreensão, que ele chama de racionalidade de nível $\mathbf{1}^{58}$. De outro lado, as teorias argumentativas enfocam a posterior etapa de fundamentação e de justificação, pois tratam dos procedimentos para legitimação formal da construção normativa, de modo a

58 STRECK, Lenio Luiz. Hermenêutica e applicatio jurídica: a concreta realização normativa do direito como superação da interpretação jurídico-metafísica-objetificante. In: DIAS, Jorge de Figueiredo. CANOTILHO, José Joaquim Gomes. COSTA, José de Faria. Ars Ivdicandi: Estudos em homenagem ao Prof. Doutor António Castanheira Neves - Filosofia, Teoria e Metodologia. V. 1. Coimbra: Coimbra Editora, 2008. p. 1103-1155. p. 1126-1127. 
refletir uma situação secundária e superficial, que ele alcunha de racionalidade de nível $2^{59}$.

Assim, para ele, a hermenêutica jurídica é preferencial e antecedente em face de quaisquer proposições argumentativas e discursivas, haja vista que se encontra no patamar da compreensão, enquanto aquelas se situam na posterior etapa de mera justificação daquilo que já foi previamente compreendido. Como decorrência desta linha de pensamento, as teorias argumentativas, discursivas ou procedimentalistas estariam relegadas a uma utilidade meramente ornamental ou decorativa, haja vista que o nível de profundidade no controle decisório reside no domínio prioritário da hermenêutica ${ }^{60}$.

Portanto, seguindo o pensamento de Streck, a dissimilitude entre as duas linhas teóricas em questão reflete precisamente no controle da interpretação, porquanto a hermenêutica trabalharia em uma dimensão prévia, calcada na justificação do mundo prático, enquanto as teorias argumentativas se contentariam com uma legitimação de segundo nível, meramente procedimental61. Mais do que isto, o referido autor entende que tal diferença de abordagem é tão profunda que implica situar as vertentes hermenêutica e argumentativa em paradigmas

$\overline{59}$ STRECK, Lenio Luiz. Hermenêutica e applicatio jurídica: a concreta realização normativa do direito como superação da interpretação jurídico-metafísica-objetificante. In: DIAS, Jorge de Figueiredo. CANOTILHO, José Joaquim Gomes. COSTA, José de Faria. Ars Ivdicandi: Estudos em homenagem ao Prof. Doutor António Castanheira Neves - Filosofia, Teoria e Metodologia. V. 1. Coimbra: Coimbra Editora, 2008. p. 1127: "De um lado, o nível apofântico, no interior do qual o jurista lida com uma racionalidade discursiva, que, com Putnam, poderia ser chamada de racionalidade II. De outro, há uma discussão a priori (racionalidade I), onde o todo da racionalidade é dado sem a argumentação, ou, melhor dizendo, onde a argumentação chega sempre tarde".

60 STRECK, Lenio Luiz. Hermenêutica e applicatio jurídica: a concreta realização normativa do direito como superação da interpretação jurídico-metafísica-objetificante. In: DIAS, Jorge de Figueiredo. CANOTILHO, José Joaquim Gomes. COSTA, José de Faria. Ars Ivdicandi: Estudos em homenagem ao Prof. Doutor António Castanheira Neves - Filosofia, Teoria e Metodologia. V. 1. Coimbra: Coimbra Editora, 2008. p. 1103-1155. p. 1122-1129, especialmente p. 1129: "Torna-se, assim, uma filosofia ornamental, o que, aliás, pode ser facilmente percebido nas diversas teorias da argumentação jurídica (ou teorias acerca da retórica no e do direito) que se multiplicam na Teoria do Direito, as quais, pensando que trabalham no nível da racionalidade - a compreensão -, acabam por se fixar no segundo nível - que é o nível (meramente) lógico-argumentativo".

61 STRECK, Lenio Luiz. Hermenêutica jurídica $\mathbf{e ( m )}$ crise: uma exploração hermenêutica da construção do direito. 8. ed. rev. atual. Porto Alegre: Do Advogado, 2009. p. 365: "Nesse sentido, a tese da resposta constitucionalmente adequada (ou a resposta correta para o caso concreto) pressupõe uma sustentação argumentativa. A diferença entre a hermenêutica e a teoria argumentativo-discursiva é que aquela trabalha com uma justificação do mundo prático, ao contrário desta, que se contenta com uma legitimação meramente procedimental". 
distintos da Ciência Jurídica62, de modo a restar inviável a tentativa do sincretismo de ambas, mediante o aproveitamento apenas de algumas partes de cada uma, para construção de uma proposta mista ${ }^{63}$.

De outro lado, Alexy não nega validade à hermenêutica como uma descrição da atividade mental de compreensão, porém submete sua utilidade à prática discursiva, a qual adquire maior importância precisamente por, primeiro, viabilizar a construção racional dos fundamentos da decisão jurídica e, segundo, por instrumentalizar o posterior escrutínio democrático.

Ao versar especificamente sobre a hermenêutica, Alexy argumenta que as visões na estrutura da compreensão do intérprete e aplicador, no quadro da Ciência do Direito, desenvolvem-se entre três modalidades distintas do círculo hermenêutico, quais sejam: a) postulado da reflexão, concernente à relação entre a pré-compreensão e o texto, que remete para crítica quanto à contribuição das experiências do intérprete para o resultado da interpretação ${ }^{64 ;}$; b) postulado da coerência, o qual diz respeito às relações entre as partes e o todo, no sentido de que o entendimento acerca de uma Norma específica pressupõe a compreensão da integralidade do sistema ao qual ela pertence e, complementarmente, o conhecimento da totalidade depende do pensar de suas parcelas constitutivas ${ }^{65}$;

62 STRECK, Lenio Luiz. Hermenêutica jurídica e(m) crise: uma exploração hermenêutica da construção do direito. 8. ed. rev. atual. Porto Alegre: Do Advogado, 2009. p. 268: "Entretanto, embora se reconheça as contribuições das correntes jusfilosóficas ligadas à retórica, à tópica e à(s) teoria(s) da argumentação, é preciso ter claro que não se pode confundi-las com a hermenêutica de cariz filosófico. Trata-se, pois, de uma questão paradigmática".

63 STRECK, Lenio Luiz. Hermenêutica jurídica $\mathbf{e}(\mathbf{m})$ crise: uma exploração hermenêutica da construção do direito. 8. ed. rev. atual. Porto Alegre: Do Advogado, 2009. p. 342: "Definitivamente, hermenêutica não é teoria da argumentação, do mesmo modo que verdade não é consenso. E não é possível lançar mão tão somente das 'partes nobres' de cada teoria (ou paradigma), descartando as insuficiências. Não é possível sincretismos metodológicos".

64 ALEXY, Robert. Direito, razão, discurso: estudos para a filosofia do direito. Porto Alegre: Do Advogado, 2010. p. 64: "Sobre uma 'pré-compreensão' deve ser entendida uma hipótese com a qual o intérprete aproxima-se do texto. Essa hipótese expressa uma presunção ou esperança do intérprete sobre a solução correta do problema jurídico pendente de decisão. Seu conteúdo é determinado pelas informações do mundo da vida e pelas experiências profissionais do intérprete. A imagem do círculo quer dizer que entre o texto da norma e a hipótese de interpretação tem lugar um efeito mútuo".

65 ALEXY, Robert. Direito, razão, discurso: estudos para a filosofia do direito. Porto Alegre: Do Advogado, 2010. p. 64-65: "Por um lado, o entender de uma norma pressupõe o entender do sistema de normas, ao qual ela pertence. Por outro, o entender de um sistema de normas não é possível sem que as normas particulares, que pertencem a ele, sejam entendidas. [...] O problema consiste na produção de unidade ou coerência. Ela é tarefa da interpretação sistemática". 
e, c) postulado da completude, que se refere à relação entre norma e fato, no sentido de que a compreensão demanda a percepção e a consideração das inúmeras características de ambos ${ }^{66}$.

Porém, embora reconheça este papel do círculo hermenêutico para a compreensão da atividade intelectual do intérprete, ele defende que se trata de questão de menor importância para a Ciência Jurídica, porquanto o controle da atividade decisória reside no momento posterior da justificação dos critérios decisórios de que tratam as teorias argumentativas. Isto porque, segundo ele, "a teoria do círculo hermenêutico não pode, com isso, solucionar o problema da interpretação correta de uma norma jurídica, porque ela não contém os critérios substanciais para correção de uma interpretação. Como nela trata-se de uma mera teoria estrutural, isso também não é o seu objetivo" ${ }^{67}$. Precisamente por isto, ele sustenta a importância preponderante das teorias argumentativas, discursivas e procedimentais, haja vista que somente por meio do discurso público (representado pelo caso especial do processo judicial) é possível compartilhar intersubjetivamente os fundamentos que justificam o resultado de uma determinada interpretação e, assim, permitir a respectiva sindicabilidade democrática ${ }^{68}$.

Tal antagonismo entre as referidas linhas gera a necessidade de se perquirir se a hermenêutica e as teorias discursivas são autoexcludentes ou, alternativamente, se devem seguir juntas no desenvolvimento da Teoria Jurídica. Ou seja, daí exsurge a questão de se a construção de um novo paradigma pós-positivista (ou então, acaso se preferir, neopositivista) merece considerar as contribuições teóricas de uma, de outra ou de ambas para o fim de ampliar os espectros descritivo e prescritivo da Ciência Jurídica.

Nesse ponto, cabe inicialmente referir que a discussão entre os adeptos de tais correntes de pensamento, aqui representados por Streck e Alexy, respectivamente,

66 ALEXY, Robert. Direito, razão, discurso: estudos para a filosofia do direito. Porto Alegre: Do Advogado, 2010. p. 65: "Normas são universal-abstratas. Os fatos, aos quais elas devem ser aplicadas, são individual-concretos. Normas contêm poucas características, fatos, potencialmente infinitamente muitas. [...] Pelo menos, está claro que o problema somente então pode ser resolvido, quando todas as características do fato e todas as características nas normas possivelmente correspondentes são consideradas".

67 ALEXY, Robert. Direito, razão, discurso: estudos para a filosofia do direito. Porto Alegre: Do Advogado, 2010. p. 65.

68 ALEXY, Robert. Direito, razão, discurso: estudos para a filosofia do direito. Porto Alegre: Do Advogado, 2010. p. 65-66. 
não reside na esfera da validade e da utilidade, haja vista que os dois polos reconhecem tais prerrogativas a ambas as construções teóricas. Sem embargo, o ponto de discussão reside apenas em conferir maior importância para uma ou outra, no sentido de defender que esforços adicionais de investigação sejam dedicados para a corrente de pensamento que, no seu entender, apresenta maior utilidade prática para o aperfeiçoamento da Teoria Jurídica.

Tanto é assim que, para Streck, "a hermenêutica não quer corrigir ou substituir qualquer teoria epistemo-procedimental", ou seja, "não proíbe que se faça essa justificação/explicitação de forma procedural", porém "não concorda com a eliminação do primeiro passo na compreensão, que é exatamente o elemento hermenêutico"69. De acordo com ele, a "filosofia hermenêutica, longe de negar qualquer aspecto da legitimidade da argumentação (ou de qualquer teoria discursiva), quer abrir o espaço em que todo o argumentar é possível"70. Outrossim, "o procedimento implica um puro espaço lógico, uma troca de argumentos. Só que cada um já vem de um lugar de compreensão, que é a précompreensão"71. Ou seja, embora tenha chegado a afirmar que hermenêutica e teorias argumentativas residam em paradigmas distintos, admite que ambos têm algum grau de relevância para a Ciência Jurídica.

Da mesma forma, Alexy admite que o fenômeno da compreensão, ou seja, o contexto da descoberta (process of discovery), é adequadamente explicitado de acordo com o círculo hermenêutico, ainda que confira maior importância às teorias argumentativas, porque enfocam o contexto da justificação dos critérios empregados para tomada de decisão (processos of justification), o qual é o locus privilegiado do controle democrático da atividade jurisdicional72.

69 STRECK, Lenio Luiz. Verdade e consenso: constituição, hermenêutica e teorias discursivas. 4. ed. São Paulo: Saraiva, 2011. p. 72.

70 STRECK, Lenio Luiz. Verdade e consenso: constituição, hermenêutica e teorias discursivas. 4. ed. São Paulo: Saraiva, 2011. p. 106.

71 STRECK, Lenio Luiz. Verdade e consenso: constituição, hermenêutica e teorias discursivas. 4. ed. São Paulo: Saraiva, 2011. p. 135.

72 ALEXY, Robert. Direito, razão, discurso: estudos para a filosofia do direito. Porto Alegre: Do Advogado, 2010. p. 65-66: A "interpretação compõe-se, por isso, da escolha entre várias alternativas de interpretação em virtude de argumentos. A justificação ou fundamentação da interpretação escolhida por argumentos deve ser distinguida do processo real de obtenção do resultado. No primeiro caso, trata-se do processo da justificação (process of justification), no segundo, do processo da descoberta (process of discovery). A justificação é uma atividade argumentativa, a descoberta uma psíquica. Sem dúvida, existem entre 
Portanto, as duas proposições teóricas permitem concluir pela possibilidade (e, mais do que isto, pela necessidade) de o aperfeiçoamento da Ciência Jurídica levar em consideração ambas, na exata medida de sua contribuição para a explicação (aspecto científico da descrição) e para a normatização (âmbito prescritivo das ciências) do fenômeno jurígeno. Ora, com a devida ressalva, é de pouca utilidade acadêmica e forense o debate sobre qual delas oferece o instrumental mais "importante" para a Teoria do Direito, cabendo considerar as contribuições de ambas para a construção de um modelo teórico mais sofisticado.

Em síntese, as duas abordagens da filosofia da linguagem antes sintetizadas (hermenêutica e teorias argumentativas) não são incompatíveis entre si e merecem ser consideradas pelo cientista jurídico. Notadamente, a análise conjunta de ambas as linhas teóricas permite a conclusão de que há dois momentos de operacionalização da linguagem, um no nível primário e pessoal (enfocado pela hermenêutica) e outro intersubjetivo (descrito pelas teorias argumentativas e discursivas), que se relacionam mutuamente em um círculo funcional, de influências recíprocas e sistêmicas. Isto porque a pessoa se insere no mundo por meio da linguagem (racionalidade pessoal) e, também, interage com outros por intermédio dela (racionalidade intersubjetiva). A linguagem, neste sentido, não apenas serve como mecanismo de raciocínio, mas também como meio para troca de conhecimentos entre pessoas, ainda que através de textos escritos ou outras formas de transmissão de mensagens ${ }^{73}$.

ambas as atividades conexões estreitas. No primeiro plano da teoria da interpretação jurídica, contudo, está o procedimento argumentativo. Somente ele é acessível intersubjetivamente e, por conseguinte, revisável objetivamente. Somente no seu quadro é possível um uso público da razão. Se com interpretações é promovida uma pretensão de correção e se o cumprimento dessa pretensão deve ser revisável publicamente, então vale a proposição: interpretação é argumentação. A isso corresponde que em sistemas jurídicos modernos regularmente existe um dever de fundamentação judicial e na ciência do direito são solucionados problemas pela consideração de argumentos-pró e contra".

73 STRECK, Lenio Luiz. Verdade e consenso: constituição, hermenêutica e teorias discursivas. 4. ed. São Paulo: Saraiva, 2011. p. 403: "Essa resposta propiciada pela hermenêutica deverá, a toda evidência, estar justificada (a fundamentação exigida pela Constituição implica a obrigação de justificar) no plano de uma argumentação racional, o que demonstra que, se a hermenêutica não pode ser confundida com teoria da argumentação, não prescinde, entretanto, de uma argumentação adequada (vetor de racionalidade de segundo nível, que funciona no plano lógico-apofântico). Afinal, se interpretar é explicitar o compreendido (Gadamer), a tarefa de explicitar o que foi compreendido é reservada às teorias discursivas e, em especial, à teoria da argumentação jurídica. Mas esta não pode se sobrepor àquela, pela simples razão de que é metódico-epistemológica". 
Nesse sentido, o sistema de signos forma um meio (medium) para o funcionamento racional das comunidades, na medida em que permite a interpretação da realidade (hermenêutica) e a transferência de informações e conhecimentos (teorias argumentativas). Com efeito, "a idealidade de generalidade do significado marca os contextos do agir comunicativo na medida em que os participantes não conseguem formular a intenção de entender-se entre si sobre algo no mundo, nem atribuir às expressões utilizadas significados idênticos, caso Ihes seja vedado apoiar-se numa linguagem comum (ou traduzível)"74.

Por isto, assim como não se pode negar a importância da hermenêutica para o estudo do fenômeno da compreensão (racionalidade dos indivíduos), também é inafastável a relevância dos métodos e das regras procedimentais como instrumentos para assegurar a comunicação racional e, assim, estimular a obtenção de verdades paradigmáticas (racionalidade intersubjetiva) ${ }^{75}$.

\section{CONSIDERAÇÕES FINAIS}

A proposta inicial deste artigo consiste em discutir sobre a importância das perspectivas filosóficas da hermenêutica e da argumentaçãojurídica para construção de um novo paradigma pós-positivista da Ciência Jurídica, muito embora possam ser apresentadas como aparentemente antagônicas ou autoexcludentes.

74 HABERMAS, Jürgen. Direito e democracia: entre facticidade e validade. V 1. Rio de Janeiro: Tempo Brasileiro, 2003. p. 38.

75 GÜNTHER, Klaus. Teoria da argumentação no direito e na moral: justificação e aplicação. São Paulo: Landy, 2004. p. 76: "Como procedimento, argumentações são processos de entendimento nos quais, sob condições especiais de interação, os participantes ingressam em um discurso buscando cooperativamente a verdade. [...] A verdade é possibilitada por regras, como franqueza e reconhecimento da repartição de encargos argumentativos. Como processo, afinal, argumentações buscam alcançar um consenso racionalmente motivado entre os participantes. Devem reinar condições gerais de simetria que excluam qualquer coação, exceto a do melhor argumento". E POSNER, Richard Allen. Para além do direito. São Paulo: Martins Fontes, 2009. p. 39: "Se, porém, um número significativo de indivíduos racionais a rejeita (e a rejeição dessa proposição não pode ser, por si só, considerada um sinal de irracionalidade, ao contrário da rejeição da proposição de que é considerado errado, em nossa sociedade, torturar crianças, ou a proposição de que a Terra gira em torno do Sol), a única maneira de resolver a discordância é através de força ou de algum método igualmente não analítico de solução de disputas, como o do voto. Não há testes, procedimentos, protocolos, algoritmos, experiências, cálculos ou observações para determinar qual dos lados da disputa está certo". 
Para tratar de tal assunto, o texto foi estrategicamente dividido em três subitens. No primeiro, foram apresentados os influxos principais da hermenêutica sobre a Teoria do Direito, de acordo com os desenvolvimentos sustentados pelo professor Streck. Do segundo, por sua vez, constou uma síntese das características centrais da teoria tida como "padrão" da argumentação jurídica, desenvolvida por Alexy. E, por fim, a terceira parte tratou da discussão sobre a compatibilidade, ou não, entre tais linhas de pensamento, com enfoque na sua utilidade para o aperfeiçoamento dos aspectos descritivo e prescritivo da Ciência Jurídica.

Ao final, a conclusão foi no sentido de que, assim como não se pode refutar a relevância da hermenêutica para o estudo do fenômeno da compreensão (racionalidade dos indivíduos), também é inegável a importância dos métodos e das regras procedimentais como instrumentos para assegurar a comunicação racional e, mais do que isto, estimular a obtenção de verdades paradigmáticas passíveis de sindicabilidade democrática (racionalidade intersubjetiva) ${ }^{76}$.

Aqui cabe ressalvar que o interesse deste texto não foijustificar uma combinação forçada entre duas linhas de pensamento antagônicas, como pode aparecer à primeira vista. Isto porque se reconhece que o cientista jurídico precisa "ter total consciência do nível teórico sob o qual estão assentadas as projeções teóricas efetuadas, ou seja, uma teoria pós-positivista não pode fazer uso de mixagens teóricas" ${ }^{177}$. Notadamente, não é possível simplesmente conjuminar as ideias de autores com posições tão diversas, como aqueles referidos neste trabalho, de 76 GÜNTHER, Klaus. Teoria da argumentação no direito e na moral: justificação e aplicação. São Paulo: Landy, 2004. p. 76: "Como procedimento, argumentações são processos de entendimento nos quais, sob condições especiais de interação, os participantes ingressam em um discurso buscando cooperativamente a verdade. [...] A verdade é possibilitada por regras, como franqueza e reconhecimento da repartição de encargos argumentativos. Como processo, afinal, argumentações buscam alcançar um consenso racionalmente motivado entre os participantes. Devem reinar condições gerais de simetria que excluam qualquer coação, exceto a do melhor argumento". E, POSNER, Richard Allen. Para além do direito. São Paulo: Martins Fontes, 2009. p. 39: "Se, porém, um número significativo de indivíduos racionais a rejeita (e a rejeição dessa proposição não pode ser, por si só, considerada um sinal de irracionalidade, ao contrário da rejeição da proposição de que é considerado errado, em nossa sociedade, torturar crianças, ou a proposição de que a Terra gira em torno do Sol), a única maneira de resolver a discordância é através de força ou de algum método igualmente não analítico de solução de disputas, como o do voto. Não há testes, procedimentos, protocolos, algoritmos, experiências, cálculos ou observações para determinar qual dos lados da disputa está certo".

77 STRECK, Lenio Luiz. Verdade e consenso: constituição, hermenêutica e teorias discursivas. 4. ed. São Paulo: Saraiva, 2011. p. 507. 
forma irresponsável, sendo absolutamente recomendado (se não necessário) extrair somente os elementos que formam entre si um quadro lógico, sistemático e harmônico, sob pena de se incorrer em um grau elevado de incongruência.

Porém, mesmo assim, as próprias considerações trazidas pelos defensores de ambas as correntes de pensamento tratados conferem viabilidade, senão imprescindibilidade, de que os avanços na teoria jurídica, tanto de perfil póspositivista como neopositivista, considerem as contribuições filosóficas de ambas as vertentes teóricas apresentadas.

\section{REFERÊNCIAS DAS FONTES CITADAS}

ALEXY, Robert. Conceito e validade do direito. São Paulo: Martins Fontes, 2009.

Constitucionalismo discursivo. 2. ed. Porto Alegre: Do Advogado, 2008.

Direito, razão, discurso: estudos para a filosofia do direito. Porto Alegre: Do Advogado, 2010.

Teoria da argumentação jurídica: a teoria do discurso racional como teoria da fundamentação jurídica. 3. ed. Rio de Janeiro: Forense, 2011.

. Teoria dos direitos fundamentais. São Paulo: Malheiros, 2008.

ATIENZA, Manuel. As razões do direito: teoria da argumentação jurídica. 2. ed. Rio de Janeiro: Forense, 2014.

. Discussão sobre neoconstitucionalismo é um acúmulo de equívocos. Consultor Jurídico. Disponível em: http://www.conjur.com.br/2015-set-05/entrevista-manuel-atienza-professoruniversidade-alicante. Acesso em 03.05.2016;

. Teorias da argumentação jurídica e hermenêutica não são incompatíveis. Consultor Jurídico. Disponível em: http://www.conjur.com.br/2015-out-08/atienza-argumentacaojuridica-hermeneutica-nao-sao-incompativeis. Acesso em: 03.05.2016.

CHAUÍ, Marilena. Introdução à história da filosofia. V. 1. 2 ed. São Paulo: Companhia das Letras, 2002.

GÜNTHER, Klaus. Teoria da argumentação no direito e na moral: justificação e aplicação. São Paulo: Landy, 2004. 
HABERMAS, Jürgen. Direito e democracia: entre facticidade e validade. V 1. Rio de Janeiro: Tempo Brasileiro, 2003.

KANT, Immanuel. Crítica da razão pura. 4. ed. Petrópolis: Vozes, 2015.

KUHN, Thomas S. A estrutura das revoluções científicas. São Paulo: Perspectiva, 2009.

PASOLD,CesarLuiz;ZANONJUNIOR, OrlandoLuiz.Pós-positivismo1:Aversão procedimentalista de Alexy. Revista Jurídica Cesumar - Mestrado, v. 13, n. 1, p. 131-159, 2013.

POSNER, Richard Allen. Para além do direito. São Paulo: Martins Fontes, 2009.

REALE, Giovanni; ANTISERI, Dario. História da filosofia: de Spinoza a Kant. V. 4. São Paulo: Paulus, 2004.

STRECK, Lenio Luiz. Hermenêutica e applicatio jurídica: a concreta realização normativa do direito como superação da interpretação jurídico-metafísica-objetificante. In: DIAS, Jorge de Figueiredo. CANOTILHO, José Joaquim Gomes; COSTA, José de Faria. Ars Ivdicandi: Estudos em homenagem ao Prof. Doutor António Castanheira Neves - Filosofia, Teoria e Metodologia. V. 1. Coimbra: Coimbra Editora, 2008. p. 1103-1155.

Hermenêutica jurídica $\mathbf{e}(\mathbf{m})$ crise: uma exploração hermenêutica da construção do direito. 8. ed. rev. atual. Porto Alegre: Do Advogado, 2009.

Verdade e consenso: constituição, hermenêutica e teorias discursivas. 4 ed. São Paulo: Saraiva, 2011.

STRECK, Lenio Luiz; OLIVEIRA, Rafael Tomaz de. Querendo ou não, para argumentar, necessito antes de hermenêutica. Consultor Jurídico. Disponível em: http://www.conjur.com.br/2015out-10/diario-classe-querendo-ou-nao-argumentar-necessito-antes-hermeneutica. Acesso em: 03.05.2016.

. É ontologicamente impossível querer mais analítica e menos hermenêutica. Consultor Jurídico. Consultor Jurídico. Disponível em: http://www.conjur.com.br/2015-set-19/diarioclasse-ontologicamente-impossivel-querer-analitica-hermeneutica. Acesso em: 03.05.2016.

ZANON JUNIOR, Orlando Luiz. Curso de filosofia jurídica. Florianópolis: Empório do Direito, 2016.

Pós-positivismo 3: a versão hermenêutica de Streck. Jus Navigandi, n. 3936, Terezina, Disponível em <www.jus.com.br>. Acesso em 01.05.2014. 
Recebido em: mai/2016

Aprovado em: ago/2016 